\title{
Ethnobotany of rural people from the boundaries of Carlos Botelho State Park, São Paulo State, Brazil
}

\author{
Natalia Hanazaki ${ }^{1,3}$, Vinícius Castro Souza ${ }^{2}$ and Ricardo Ribeiro Rodrigues ${ }^{2}$
}

Received: February 16, 2006. Accepted: July 01, 2006

\begin{abstract}
RESUMO - (Etnobotânica de uma população rural próxima do Parque Estadual Carlos Botelho, SP, Brasil). Neste estudo, nós descrevemos e analisamos o uso de recursos vegetais em uma região próxima a uma área de conservação. Os dados foram coletados através de entrevistas semi-estruturadas, incluindo listagens livres dos recursos vegetais conhecidos. As espécies foram identificadas através de coletas botânicas e de observações de campo. Foram entrevistados 58 habitantes; cultivo de banana, trabalho em fazendas de gado e extração de palmito são suas atividades econômicas principais. Foram mencionadas 248 etnoespécies, correspondendo a mais de 200 espécies botânicas. As plantas foram agrupadas em quatro habitats $(A=$ floresta bem preservada; $B=$ floresta perturbada, em estágios successionais avançados; $\mathrm{C}=$ ambientes recentemente perturbados; $\mathrm{D}=$ áreas cultivadas e quintais). Uma maior diversidade foi encontrada para o habitat $\mathrm{A}$, seguido por $\mathrm{C}+\mathrm{D}$, e finalmente por áreas $\mathrm{B}$; entretanto, é esperada uma riqueza maior de espécies para a área $\mathrm{B}$ quando comparada a C+D. Há poucas espécies comuns, e proporções comparáveis de espécies intermediárias e raras, para todos os habitats. As espécies comuns ocorrem em todos os tipos de habitats. O conhecimento local das plantas dos habitats bem preservados é mais diverso do que para plantas de outras áreas, sugerindo que a relação entre habitantes e a área de conservação é ainda intensa.
\end{abstract}

Palavras-chave: Floresta Atlântica, diversidade, etnobotânica, conhecimento ecológico tradicional, áreas perturbadas

\begin{abstract}
Ethnobotany of rural people from the boundaries of Carlos Botelho State Park, São Paulo State, Brazil). In this article we describe and analyze the use of plant resources in a region nearby a conservation area. Data were collected through semi-structured interviews, in which we asked the interviewees to free list the plants known. Species cited were identified through collection of botanical samples, and field observations. Fifty-eight inhabitants were interviewed; banana farming, cattle ranching, and extracting palm hearts are their main economic activities. A total of 248 ethnospecies were mentioned, including over 200 botanical species. Plants were grouped into four habitats $(\mathrm{A}=$ well-preserved forest; $\mathrm{B}=$ disturbed forest in old successional stages; $\mathrm{C}=$ recently disturbed environments; $\mathrm{D}=$ cultivated areas and home gardens). Highest diversity is known for plants from A habitats, followed by C+D, and finally by B areas; however, a higher number of species is expected in $\mathrm{B}$ areas when compared to $\mathrm{C}+\mathrm{D}$. There is a small number of common species, and comparable proportions of intermediate and rare species, for all habitats. Common species occur in all types of habitats. Local knowledge of plants from well-preserved habitats is more diverse than for plants from other areas, suggesting that the relationship between inhabitants and the conservation area is still intense.
\end{abstract}

Key words: Atlantic forest, diversity, ethnobotany, traditional ecological knowledge, disturbed areas

\section{Introduction}

The Atlantic Forest is the second largest tropical rain forest of Brazil, following the Amazon. Reduced in its area, with less than $10 \%$ of its original range remaining, this biome tops the list of Brazilian conservation priorities, due to its high endemism, diversity, and threats of habitat destruction (Myers et al. 2000). The scenario of habitat destruction has historical roots in Brazilian colonization (Dean 1996) and was intensified in the last century with the presence of the largest Brazilian urban centers, such as São Paulo and Rio de Janeiro, and pressures related to agricultural growth, real estate speculation and the expansion of tourism.

Despite these major pressures, there are also native and rural inhabitants living near the forested areas and, in many instances, depending directly on the forest for some of their livelihood. Focusing on this relationship between people and plants (Schultes \& Reis 1995;

\footnotetext{
1 Universidade Federal de Santa Catarina, Centro de Ciências Biológicas, Departamento de Ecologia e Zoologia, Campus Universitário Trindade, 88010-970 Florianópolis, SC, Brazil (Bolsista FAPESP)

2 Universidade de São Paulo, Escola Superior de Agricultura Luiz de Queiroz, Departamento de Ciências Biológicas, Av. Pádua Dias 11, C. Postal 9, 13418-900 Piracicaba, SP, Brazil

3 Corresponding author: natalia@ccb.ufsc.br
} 
Minnis 2000), ethnobotanical studies in Brazilian Atlantic Forest have grown in the last decade. Instead of essentially descriptive studies, quantitative approaches have been developed and applied, such as in the case of ethnobotany of native inhabitants of the Atlantic coast - the caiçaras (Begossi et al. 1993; 2002; Figueiredo et al. 1993; 1997; Rossato et al. 1999; Hanazaki et al. 2000; Peroni \& Hanazaki 2002). The paramount importance of these studies is associated with the presence of human settlements near areas topped for conservation priorities, especially when some local practices, knowledge, and skills are valued for conservation purposes. It is not by a chance that some native populations remain near the last fragments of Brazilian Atlantic Forest, often overlapping conservation areas. The conservationist debate over areas free from people versus areas where conservation and use could be coupled is not a new one (Zube \& Busch 1990; Schimink et al. 1992; Kemf 1993; Schwartzman et al. 2000; Peres \& Zimmerman 2001). Ethnobotany studies can contribute to this debate, analyzing how local people identify and use the forest resources, and which areas and which species are used most intensively (La Torre-Cuadros \& Islebe 2003; Dalle \& Potvin 2004). This view is embedded with the in situ conservation perspective, which includes the aims of maintain the forest together with some of the cultural relationships between people and plants (Tuxill \& Nabhan 2001).

In spite of these studies focused on ethnobotany of settlements of the Brazilian Atlantic Forest coast, inhabited by farmer-fishermen, very few studies analyze the knowledge and use of plant resources by other rural communities (Voeks 1996; 2004; Di Stasi et al. 2002; Medeiros et al. 2004; Voeks \& Leony 2004; Silva \& Andrade 2005). Rural communities in Brazil include a wide range of cultural influences (Ribeiro 1995) and, in some cases, when they share characteristics such as self-determination, production for subsistence, local institutions, and reinforced cultural traits; they are considered to be traditional people (Diegues \& Arruda 2001). In other instances, these characteristics are almost absent, and rural people encompass inhabitants from different regions of the country as well as people native to urban and periurban areas.

The main aspect investigated in Atlantic Forest ethnobotany is the use of medicinal plants, influenced by the development of ethnopharmacological studies and by numerous investigations on medicinal plants (see Schultes \& Reis 1995; Balick \& Cox 1996). Other plant species with non-medicinal uses are heavily exploited in Brazilian Atlantic Forest, such as palm hearts ("palmito juçara", Euterpe edulis Mart.) extraction, generating chronic socio-environmental conflicts due to the illegal status of such activities. Besides the knowledge of medicinal resources and the controversial extraction of palm hearts, the local inhabitants are expected to have some knowledge of the local flora. The aim of this paper is to describe and analyze the use of plant resources (medicinal and nonmedicinal) in a region near a conservation area, the Carlos Botelho State Park, focusing on tree species. Specifically, we are interested in investigating which kind of plant resources are identified and used by people living near a relatively well-preserved conservation area.

\section{Methods}

Study site - Brazilian Atlantic rainforest is characterized by a complex of vegetation types, including the forests in mountain slopes, the coastal plains with swamp forests, dry semideciduous forests and open thicket vegetation on marine sand deposits (Scarano 2002). The forest area in the studied region is characterized as an ombrophilous dense forest (Veloso \& Góes Filho 1982), with a high diversity of tree species. Custódio Filho et al. (1992) registered 176 tree species, estimating a total richness of about 250 tree species for the Carlos Botelho State Park area. According to O.C. Negreiros (unpublished data), the trees with higher importance value include Bathysa sp., Euterpe edulis Mart., Sloanea sp., Tetrastylidum sp., several Myrtaceae, Cryptocarya sp., Nectandra sp., Chrysophyllum sp., Hieronima sp., Cupania sp., Cabralea sp., Inga sp. and Torrubia sp.

The study area encompasses the rural communities on the southern boundary of Carlos Botelho State Park, in the southern part of São Paulo State, Brazil. With an area of 37,644 ha, this conservation area was constituted in 1982 by the fusion of four reserves created in the 1940s. An ancient trail used to transport cattle and goods was enlarged, before the creation of the reserves, and transformed into a road that runs $33 \mathrm{~km}$ across the Park, connecting the towns of São Miguel Arcanjo and Sete Barras. The Park has no local inhabitants living inside its boundaries, yet the presence of the road is a constant threat to conservation.

This study focuses on the rural communities located in the municipality of Sete Barras, at the southern boundary of Carlos Botelho State Park. The area 
belongs to a region widely known as Ribeira Valley, a region that has been relatively isolated from the Brazilian economic mainstream due to historical factors and to the lack of infrastructure to overcome its biophysical limitations. As a result, this region presents the lowest indices of literacy and income in São Paulo State, and the largest concentration of continuous Atlantic Forest remnants in Brazil (Hogan et al. 1999).

The municipality of Sete Barras has about 13,900 inhabitants, with $66 \%$ of this population living in the rural area (IBGE 2002). Banana plantations are responsible for most of the agricultural production in this region. Other economic activities in the rural area are small-scale cattle ranching, fruit crops, and palmheart planting and extraction. According to the official census (IBGE 2002), the latter activity is responsible for less than half percent of the local economy. However, it is an outstanding and conflicting activity, which involves illegal extraction of a forest resource (Orlande et al. 1996; Reis et al. 2000), and these figures can be underestimated.

The rural inhabitants of the region are composed mainly of laborers on banana plantations and small farmers. Some of them probably have some proportion of Amerindian blood, however they are not Indians. They are primarily from European-colonizer and African-slave stock, constituting the typical Brazilian rural people (Cândido 1977; Ribeiro 1995). These native inhabitants are not considered strictly to be traditional people, because they are not self-determined as such (Cunha \& Almeida 2000), yet they have lived in this region for generations and share broad characteristics of the rural Brazilian inhabitants. There is high mobility among the local families, as temporary laborers on banana farms. A preliminary survey indicates that about 10 percent of the houses along the SP-139 road were abandoned, and about a quarter were closed.

Data collection - Fieldwork was done from 2002 to 2004. We selected the communities closest to the southern boundary of the Carlos Botelho State Park, along the road. We explained the purpose of the research after preliminary contact with the interviewees. Data were then collected through semistructured interviews, with adult residents who agreed to take part in the research. The sampling effort corresponded to $50 \%$ of the houses, interviewing inhabitants in one out of two houses. We interviewed both male and female inhabitants, separately, who had lived in the region for at least two years. Refusal to participate in the interview occurred in $7 \%$ of the contacted residents. After a socio-economic characterization, we asked each interviewee to free list the plant resources he or she knew. Directed questions were used to investigate particular aspects of local knowledge, regarding plants for medicine ("plants used for remedies"), food ("edible plants" or "plants with edible fruits"), handicrafts ("plants used by artisans and for construction"), wood and timber, and firewood. For each cited taxon we asked about its uses and where the plant could be found (e.g. home gardens, near the road, anthropic environments, secondary succession, forest, swamps).

Cited plants were collected with the help of each interviewee. Plants widely known, such as orange, banana and other well-known plants were identified in situ. Plant vouchers were deposited in the ESA herbarium (University of São Paulo, Brazil).

Data analysis - The plant ethnotaxonomy was briefly analyzed and compared with the classic hierarchical ranks proposed by Berlin et al. (1973) and Berlin (1992), considering the information present in all interviews as a group.

The species mentioned were grouped according to habitat in four main types. These types were previously defined (Peroni \& Hanazaki 2002; Hanazaki et al. 2005) and they match general perceptions of the local inhabitants of Brazilian Atlantic forest in four emic categories. In this specific case, the assumption of similar semantic meaning in classifications of local people and conservation professionals is realistic, since the local users are not strictly traditional people (see Casagrande 2004 for further discussion). Type A habitats correspond to well-preserved forest (or, according to the interviewees, "mata"). The major area of this kind of forest is the Carlos Botelho State Park. However, a few other fragments were found throughout the region. Type B habitats correspond to the forest once altered by deforestation, yet at successional stages up to 50 years from the last deforestation (or "capoeirão"). Type C habitats correspond to environments directly and recently disturbed by human activities (or "capoeira"). This type also includes anthropic environments such as the edges of roads and trails, semi-abandoned yards and noncultivated areas around houses. Type D habitats include cultivated areas, both productive plots (or "roças") and managed home gardens (for further discussion on management intensity and environments, see Hanazaki et al. 2005). Since this paper stresses the 
ethnobotanical knowledge in forest areas, types $\mathrm{C}$ and $\mathrm{D}$ were grouped together for further diversity analysis.

The salience of a plant listed by respondents refers to its psychological prominence (Quinlan et al. 2002), and can be calculated through free-listing interviews (Bernard 1995) that combine the frequency of plant citation with the order of citation (Robbins \& Nolan 1997). Salience relies on the fact that: a) the respondents tend to mention the most culturally important items first in a list, and b) the best-known plants are usually listed more frequently (Trotter \& Logan 1986; Quinlan et al. 2002).

Hill's diversity numbers were used to compare proportions of rare, intermediate and common species (Magurran 1988; Williams et al. 2005). Hill's numbers provide a method to describe the relationship between diversity indices (Magurran 1988) and, according to Williams et al. (2005), the values of N1 (ShannonWiener, base $e$ ), N2 (reciprocal of Simpson's index, $1 / \mathrm{D})$ and $\mathrm{N} \infty$ (reciprocal of the proportional abundance of the commonest species, or reciprocal of BergerParker index), corresponding to measures of abundant, very abundant, and most abundant species in a sample, respectively. The value of $\mathrm{N} \infty$ can be interpreted as a measure of the common species, N1-Nocan be interpreted as a measure of the number of intermediate species, and N0-N1 corresponds to a measure of rare ones. Other diversity comparisons followed Begossi (1996) and Hanazaki et al. (2000) and included the estimated richness for a rarefacted sample and Shannon-Wiener comparisons using a modified $t$ test (Magurran 1988; Hanazaki 2004).

\section{Results and discussion}

The interviewees - Fifty-eight local inhabitants were interviewed, with ages ranging from 18 to 93 years (mean $=49$ yrs, s.d. $=18.9 \mathrm{yrs}$ ), corresponding to 30 women and $28 \mathrm{men}$. The households have an average of four members. About 38\% of the interviewees were born outside the Ribeira Valley Region. These outsiders averaged 50 years old (s.d. $=17.2 \mathrm{yrs}$ ) and have lived in the region for 23 years on average (s.d. $=12.5 \mathrm{yrs}$ ). More than a quarter of the interviewees are illiterate and more than half only attended primary school (up to four years). Only three percent of the interviewees reached higher levels.

The main economic activities of the inhabitants of this region are related to banana farms, cattle ranching and extraction of palm hearts. Less than a half of the interviewees own their land. Most of the inhabitants live in rented houses or in rent-free houses lent by their owners. Four small-property owners were planting seedlings of Euterpe edulis Mart. and other palms such as Archontophoenix alexandrae (F. Muell.) H. Wendl. \& Drude and Euterpe oleracea Mart. in order to produce palm hearts in secondary forests on their property. Two of these owners mentioned that they intend to replace banana crops with restored forest, to produce palms in the understory. However, the illegal extraction of E. edulis is still practiced in the region and represents one of the major threats to biological diversity in this area (Orlande et al. 1996; Matos \& Bovi 2002).

The average per capita income is $\mathrm{R} \$ 101.97$, with a high standard average of $\mathrm{R} \$ 96.29$, pointing to social stratification in the sampled area (in June 2002, $\mathrm{R} \$ 1.00=\mathrm{US} \$ 0.37)$. Highest per capita income was from families that own their land and have banana farms, employing local labor. Families with the lowest incomes were those who live in areas owned by their employers and who work for monthly wages or are paid on a daily basis (a day of work in the banana fields earns about $\mathrm{R} \$ 10.00)$. Also included in this group are the small banana farmers and "posseiros" (people who have land tenure through use over time).

Plant knowledge - Plant ethnotaxonomy compared to the classical hierarchical ranks proposed by Berlin et al. (1973) and Berlin (1992) is exemplified in Fig. 1. The local perception of the plant world has some slight differences from the standard urban Brazilian perception. According to the interviewees, there is no name for the unique beginner rank, and no name for the plant world. The taxon "planta" is restricted to the cultivated plants, such as "laranja" (orange), "banana", and "mandioca" (cassava). The local knowledge related to the native trees can be detailed in the taxon "árvore" and under the dichotomy "árvore de cerne" and not"árvore de cerne". The latter refers to the native trees used for firewood and other purposes, and the former differentiates the native trees used preponderantly as timber (also known as "madeira de lei"). Other details were related to trees with edible fruits, and trees used for medicinal purposes.

The entire group of interviewees $(n=58)$ mentioned a total of 731 citations, corresponding to 248 ethnospecies (Hanazaki et al. 2000, or generic plant folk taxa, following Berlin 1992, see also Fig. 1). Among the 248 ethnospecies, 25 names were synonyms, according to the interviewees. Binomial names account for $14.9 \%$ of the generic plant taxa. One-to-one correspondence was observed with 223 


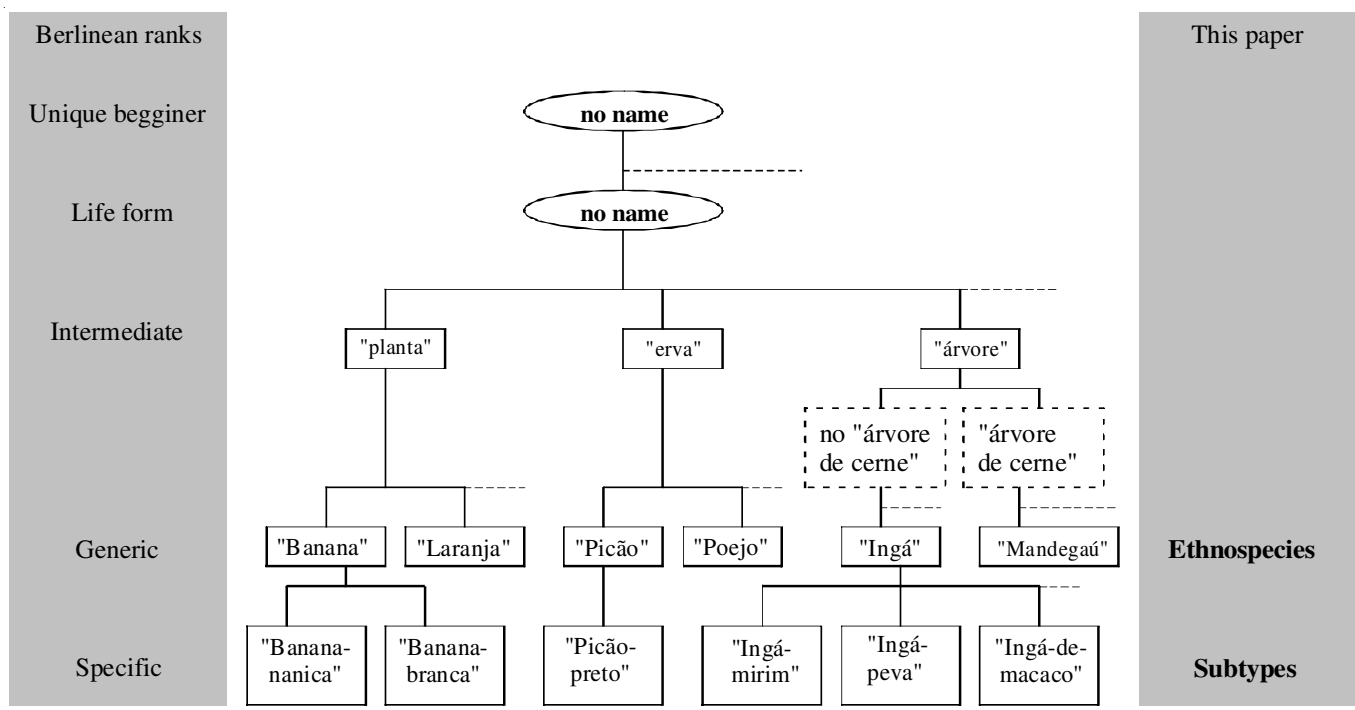

Figure 1. A model for the ethnotaxonomy of plant resources cited by the interviewees at the southern boundary of Carlos Botelho State Park, Brazil.

plant species. The synonyms included names with slightly different sounds, such as the inversions of /Z/ with $/ \mathrm{J} /$, in the case of "jacatirão" and "nhacatirão". Synonyms also included different names attributed to the same reference plant, such as "caquera" and "quaresmeira" (Senna multijuga (Rich) Irwin et Barn.).

Local varieties (or specific plant folk taxa, following Berlin 1992) were considered to be subtypes of a given generic plant taxon, even if it corresponds to different botanical species, such as in the case of Ingas (ethnospecies, or generic taxon Inga; subtypes "ingámirim", "ingá-peva”, "ingá-de-macaco", "ingá-ferro").

Plant uses and environments - A similar proportion of plant citations was observed for habitat types A (wellpreserved forest, 36\%) and D (cultivated areas and home gardens directly managed, $31 \%$ ), followed by type B (old successional stages, $22 \%$ ), and finally type $\mathrm{C}$ habitats (recently disturbed areas, 11\%). Nevertheless, if we consider habitats $\mathrm{C}+\mathrm{D}$ together, a highest proportion of plants (42\%) corresponds to this group. According to Chazdon \& Coe (1999), second-growth forests have high utilitarian value as well as conservation value, and will likely become important sources of forest products. The importance of secondary forest as a source of ethnobotanical information was also stressed by other authors (Toledo et al. 1995). Especially for medicinal plants with herbaceous and/or weedy habits, cultivated areas and home gardens directly managed are important environments for its collection. Voeks (2004) discussed the dependence on successional mosaics for plant medicinal resources in Atlantic forest areas. The association between directly managed habitats and plant medicinal resources configures a pattern well documented in ethnobotanical literature (Bennett \& Prance 2000; Stepp \& Moerman 2001; Stepp 2004; Albuquerque et al. 2005; Estomba et al. 2006). However, we agree with Casagrande (2004) when he considered that there are problems in generalizing these results, because the importance of well-preserved forest varies between types of products (e.g. medicinal, construction materials), and because the economic and ecological relationships are unique in each case (e.g. market pressures towards different forest resources). For example, regarding wild edible plants, Ladio \& Lozada (2004) found that the greatest total richness and highest diversity of plants come from distant forest environments, and not from areas nearby homes.

Five general use categories were observed (Tab. 1). The majority of ethnospecies cited have only one general use (63\%). Plants with two general uses made up $31 \%$ of the cited taxa, and only $6 \%$ of the plants were used for three general purposes. The highest number of species was used for medicinal purposes, followed by plants for timber and for food. However, the majority of medicinal plants are obtained from habitats $\mathrm{C}$ and $\mathrm{D}$, when compared to $\mathrm{A}$ or $\mathrm{B}$ $\left(\chi^{2}=37.80, \mathrm{p}<0.01,2 \mathrm{df}\right)$. The same was observed for edible plants $\left(\chi^{2}=14.14, p<0.01 .2 d f\right)$. On the 
Table 1. Main uses of cited plants, according to the interviewees. Values in parentheses indicate the percent of each use in relation to the total uses, for 282 citations of uses attributed to the 223 plants.

\begin{tabular}{|c|c|}
\hline Use & Description \\
\hline Medicine (30\%) & $\begin{array}{l}\text { Leaves used for infusion, cataplasm, baths. Bark used in alcoholic beverages. Resins, roots and fruits are rarely } \\
\text { used. Used to treat common symptoms of colds, flu, headaches, toothaches, stomachaches, kidney malfunctions, } \\
\text { high blood pressure, intestinal worms, to heal wounds, rheumatism, bladder, dysentery, indigestion, eczema, } \\
\text { menstrual pains, measles, among others. }\end{array}$ \\
\hline Wood $(24 \%)$ & $\begin{array}{l}\text { For construction of houses and some furniture; manufacturing of handles; manufacturing of canoes, fence posts, } \\
\text { and wooden wagons. }\end{array}$ \\
\hline Food $(23 \%)$ & Edible fruits eaten raw or as juice; edible tubers and palm hearts eaten cooked; leaves used as a seasoning. \\
\hline Firewood $(9 \%)$ & Low-quality wood for timber, either dry or, in some cases, recently cut. \\
\hline Handicrafts $(7 \%)$ & Mainly lianas and climbers to provide fibers for handicrafts such as baskets, brooms, mats, fish traps, hats. \\
\hline Other $(7 \%)$ & $\begin{array}{l}\text { Commercial uses (palm heart and some ornamentals), ornamental uses, fruits used to attract small mammals and } \\
\text { birds, fruits used as bait, magic uses (to protect against "evil-eye"). }\end{array}$ \\
\hline
\end{tabular}

other hand, the majority of plants used to provide wood are obtained from A habitats $\left(\chi^{2}=37.48, \mathrm{p}<0.01,2\right.$ df), and plants used for firewood are collected from B habitats $\left(\chi^{2}=22.67, \mathrm{p}<0.01,2 \mathrm{df}\right)$. Plants used for handicrafts and other uses have a similar distribution among the habitats $\left(\chi^{2}=0.88, \mathrm{p}>0.01,2 \mathrm{df}\right)$, that is, one type of environment does not predominate over the others.

The group of species used for medicinal purposes are mainly herbaceous plants, from type D habitats, which agrees with the findings of Albuquerque et al. (2005), Stepp (2004) and Stepp \& Moerman (2001), among others. Medicinal plants commonly used correspond to the main species used elsewhere in Atlantic Forest communities (Begossi et al. 2002; Di Stasi et al. 2002) and in other Brazilian regions, such as Mentha piperita L., Cymbopogon citratus (DC.) Stapf., Psidium guajava Raddi, M. pulegium L., and Plectranthus barbatus Andrews.

Assessing woody species for timber, medicine and other uses, Chazdon \& Coe (1999) found that in the Atlantic Forest of Costa Rica, species richness was highest for medicinal species. Amongst the woody species found in our study, very few are used for medicinal purposes. Trees are collected in habitat types $\mathrm{A}$ and $\mathrm{B}$, and are used for timber and wood, and in a few cases to attract game animals and birds. Firewood is obtained in disturbed areas, near homes, and on the edge of old-successional fragments. The understory of old-successional fragments is used by some land owners to cultivate palms, and occasionally to extract other forest products such as edible fruits and wood for fences and tool handles.
Ethnobotanical knowledge differs between men and women. For habitats A and B, men mentioned over twice as many species as women. In contrast, for types $\mathrm{C}$ and $\mathrm{D}$, women mentioned more species than men. These gender differences were observed elsewhere (Rossato et al. 1999; Voeks \& Leony 2004; Lawrence et al. 2005) and reflect the lower mobility of women when compared to men. Women are more restricted to the domestic environment, and have a profound knowledge of the local pharmacopoeias based on herbs and cultivated plants near residences. The knowledge of species from habitats types A and B reflects the particularities of the knowledge about native species, especially trees. On the other hand, men have a higher mobility due to their economic activities (Rossato et al. 1999). In the study area, this mobility was often associated with palm-heart extraction and past timber extraction. The extraction of timber and wood resources is a typical male job, except for the extraction of some firewood from type B habitats which is also practiced by women. Additionally, the tree species mentioned by more than $15 \%$ of the interviewees indicated a higher salience among men than among women (Fig. 2). Considering these species, the two with highest saliences for women were jacatirão (Miconia cinnamomifolia (DC.) Naudin) and goiaba (Psidium guajava L.). The first is a source of firewood collected in type B habitats near homes and also has a high visual salience (lilac flowers). The latter produces a prized fruit frequently present in home gardens and, although it is widely used as medicinal in other places, no mention of medicinal use was recorded in this study. 


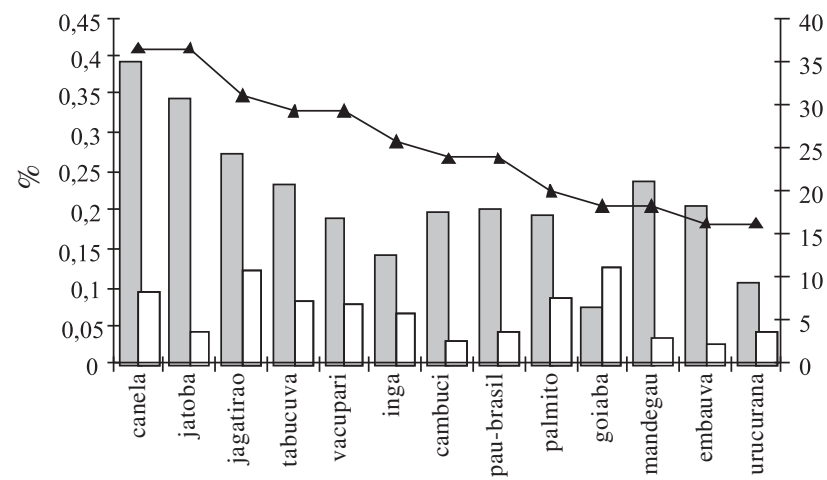

Figure 2. Frequency of citations (right scale) of the most cited trees and salience index (left scale) according to men and women. ( $\square$ = Men; $\square=$ Women; $-\mathbf{-}-=$ Citations).

Diversity - A highest plant diversity was cited for plants from type A habitats (well-preserved forest), when compared to type B (old successional forest) and types $\mathrm{C}+\mathrm{D}$ (recently disturbed areas). Using rarefaction curves (Magurran 1988; Begossi 1996; Williams et al. 2005), we observe that for the same number of interviews, there is a higher number of expected species from well preserved forest, followed by recently disturbed environments and old successional vegetation (Fig. 3).

Shannon-Wiener (base e) indexes for these three groups also show this pattern, with highest values for type A habitats, followed by $\mathrm{C}+\mathrm{D}$ and $\mathrm{B}$ habitats (Tab. 2). The difference between Shannon-Wiener indexes was statistically significant for types A and B, types $\mathrm{A}$ and $\mathrm{C}+\mathrm{D}$, and types $\mathrm{B}$ and $\mathrm{C}+\mathrm{D}\left(t_{\mathrm{A}, \mathrm{B}}=6.984\right.$, $564.327 \mathrm{df} ; t_{\mathrm{A}, \mathrm{C}+\mathrm{D}}=3.079,671.401 \mathrm{df} ; t_{\mathrm{B}, \mathrm{C}+\mathrm{D}}=3.939$, $562.441 \mathrm{df})$. These figures indicate that we observe the highest diversity in well-preserved areas, followed by disturbed areas, and finally by old successional areas; however, a higher number of species is expected

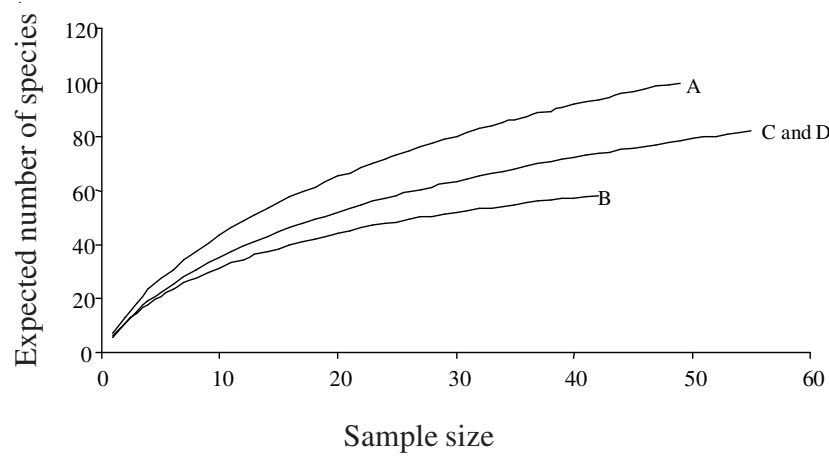

Figure 3. Rarefaction curves for plants cited in each environment ( $\mathrm{A}=$ well-preserved forest $\mathrm{B}$ = disturbed forest in old successional stages; $\mathrm{C}$ and $\mathrm{D}=$ recently disturbed and cultivated areas).
Table 2. Diversity measures for plants cited in each environment ( $\mathrm{A}=$ well preserved forest; $\mathrm{B}=$ disturbed environment in old successional stages; $\mathrm{C}$ and $\mathrm{D}=$ recently disturbed or cultivated areas).

\begin{tabular}{|c|c|c|c|}
\hline & A & B & $\mathrm{C}$ and $\mathrm{D}$ \\
\hline Richness (S, or N0) & 100 & 58 & 82 \\
\hline $\begin{array}{l}\text { Shannon-Wiener (base e) } \\
\text { (H', or N1) }\end{array}$ & 4.139 & 3.605 & 3.912 \\
\hline $\begin{array}{l}\text { Reciprocal of Simpson } \\
\quad(1 / \mathrm{D}, \text { or } \mathrm{N} 2)\end{array}$ & 43.098 & 26.426 & 34.482 \\
\hline $\begin{array}{l}\text { Reciprocal of Berger-Parker } \\
\quad(1 / \mathrm{d}, \text { or N") }\end{array}$ & 17.400 & 12.804 & 14.864 \\
\hline $\mathrm{H}_{\max }$ & 4.605 & 4.060 & 4.407 \\
\hline Citations & 348 & 256 & 327 \\
\hline
\end{tabular}

in old successional areas when compared to recently disturbed areas (Fig. 3). It is important to stress that, since diversity indexes applied to ethnobotanical information are based on citations from interviews; they do not directly reflect the species diversity in each environment. If the ecological apparency affects the use of a given species, we should expect this relation to be true. However, Albuquerque and Lucena (2005) have shown that there is no consistent evidence yet to affirm that these relationships are constant.

The comparison of rare, intermediate, and common species among the habitats resulted in a small number of common species, and comparable proportions of intermediate and rare species, for all the environments (Fig. 4). Following Williams et al. (2005), in the markets of Johannesburg, the number of species represented by $\mathrm{N} 2$ and $\mathrm{N} \infty$ (common species) are indicators of the number of ethnospecies that are candidates for more immediate conservation action, reflecting the commonness or dominance of the species in the sample. In the region of Carlos Botelho State Park, we identified 42 common species from habitat $\mathrm{A}$, the same number from habitat $\mathrm{B}$, and 55 common species from habitats $\mathrm{C}+\mathrm{D}$. Among the 34 common species identified according to Hill's numbers and cited per $10 \%$ or more interviewees, only nine can be considered non-native to Atlantic Forest region (Tab. 3). These nine species correspond to edible fruit trees cultivated in home gardens (e.g. Persea americana Mill., Citrus sinensis (L.) Osbeck, Artocarpus integrifolia L.) or even farms (Musa) or medicinal herbs (Cymbopogon citratus Stapf, Mentha $\times$ piperita L., M. pulegium L., Melissa offincinalis L.). The common native trees according to the interviewees include species which produce edible fruits as well, such as Campomanesia 


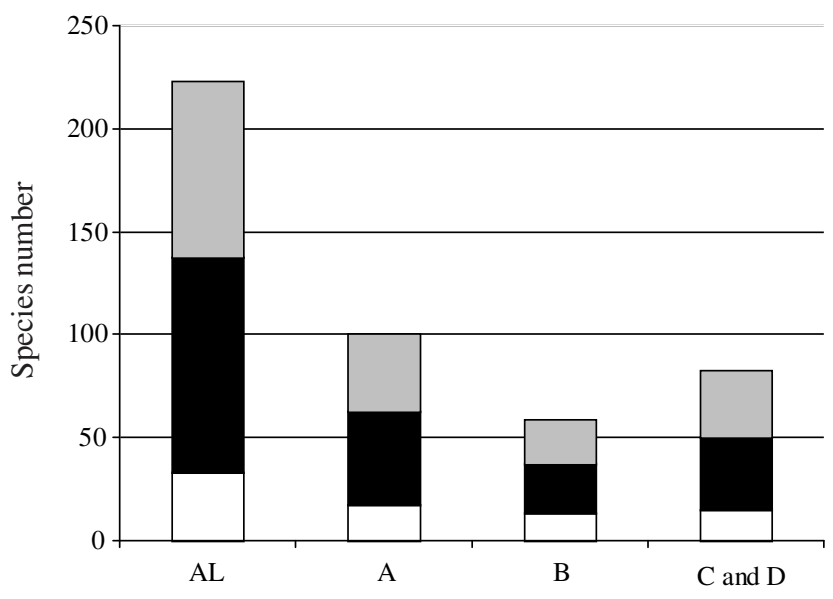

Figure 4. Number of plants in each category of Hill's numbers (see text for further explanation), for all plants and for plants in each environment $(\mathrm{A}=$ well-preserved forest; $\mathrm{B}=$ disturbed forest in old successional stages; $\mathrm{C}$ and $\mathrm{D}=$ recently disturbed and cultivated areas). ( $\square=$ Rare; $\mathbf{\square}=$ Intemediate; $\square=$ Commom $)$. phaea (O. Berg) Landrum, Garcinia gardneriana (Planch \& Triana) Zappi, and Psidium cattleyanum Sabine. The first species has already been identified as a potentially economic fruit (Kawaski and Landrum 1997); the others were mentioned in other parts of Brazilian Atlantic forest as important edible fruits (Hanazaki et al. 2000). The use of these species is potentially interesting since a standing tree bearing fruits is more valuable for conservation than a timber tree.

According to these criteria, it is possible to set priorities for a group of species for conservation purposes, including $C$. phaea (O. Berg) Landrum, Cryptocarya moschata Nees \& Mart., Inga spp., Hymenaea courbaril L., Tetrastylidium grandifolium (Baill.) Sleumer., G. gardneriana (Planch \& Triana) Zappi, and Eugenia multicostata Legr. (Tab. 3). These species share characteristics of being commonly

Table 3. Common species (according to Hill's numbers and with more than $10 \%$ of citations) in each environment. Introduced species are marked with an asterisk (A: well-preserved forest, $n=42$; B: disturbed forest in old successional stages, $n=42$; CD: recently disturbed or cultivated areas, $n=55)$. Data in percentage.

\begin{tabular}{|c|c|c|c|c|c|}
\hline Ethnospecies & Botanical species & Family & A & $\mathrm{B}$ & $\mathrm{CD}$ \\
\hline Abacate & Persea americana Mill.* & Lauraceae & 0 & 0 & 15 \\
\hline Araçá & Psidium cattleianum Sabine & Myrtaceae & 14 & 0 & 11 \\
\hline Banana & Musa $\times$ acuminata Colla* & Musaceae & 0 & 0 & 11 \\
\hline Boldo & Plectranthus barbatus Andrews* & Lamiaceae & 0 & 0 & 38 \\
\hline Bucuúva & Virola bicuhyba (Schott) Warb. & Myristicaceae & 14 & 0 & 0 \\
\hline Cambuci & Campomanesia phaea (O. Berg) Landrum & Myrtaceae & 31 & 31 & 24 \\
\hline Canela & Cryptocarya moschata Nees \& Mart. & Lauraceae & 48 & 48 & 0 \\
\hline Capim-santo $^{1}$ & Cymbopogon citratus Stapf* & Poaceae & 0 & 0 & 24 \\
\hline Caquera $^{2}$ & Senna multijuga (Rich) Irwin \& Barn. & Caesalpiniaceae & 0 & 19 & 0 \\
\hline Carqueja & Baccharis trimera (Less) DC & Asteraceae & 0 & 0 & 16 \\
\hline Embaúba & Cecropia glaziovii Snethl. & Cecropiaceae & 0 & 21 & 0 \\
\hline Erva-cidreira & Melissa officinalis L.* & Lamiaceae & 0 & 0 & 18 \\
\hline Figueira & Ficus sp. & Moraceae & 19 & 0 & 0 \\
\hline Goiaba & Psidium guajava $\mathrm{L}$. & Myrtaceae & 24 & 0 & 18 \\
\hline Hortelã & Mentha $\times$ piperita $\mathrm{L} . *$ & Lamiaceae & 0 & 0 & 40 \\
\hline Ingá & Inga spp. & Mimosaceae & 33 & 33 & 25 \\
\hline Jabuticaba & Myrciaria floribunda (West ex Willd.) Berg & Myrtaceae & 19 & 0 & 15 \\
\hline Jaca & Artocarpus integrifolia L.* & Moraceae & 0 & 0 & 11 \\
\hline Jacataúva & Citharexylum myrianthum Cham. & Verbenaceae & 0 & 14 & 0 \\
\hline Jacatirão $^{3}$ & Miconia cinnamomifolia (DC.) Naudin & Melastomataceae & 0 & 40 & 0 \\
\hline Jambro & Eugenia oblongata $(\mathrm{CF})$ & Myrtaceae & 0 & 0 & 11 \\
\hline Jatobá & Hymenaea courbaril $\mathrm{L}$. & Caesalpiniaceae & 48 & 48 & 0 \\
\hline Juçara $^{4}$ & Euterpe edulis Mart. & Arecaceae & 26 & 0 & 20 \\
\hline Limão & Citrus sinensis (L.) Osbeck* & Rutaceae & 0 & 0 & 11 \\
\hline Mandegaú & Tetrastylidium grandifolium (Baill.) Sleumer. & Olacaceae & 24 & 24 & 0 \\
\hline Pau-brasil & Eugenia multicostata Legr. & Myrtaceae & 31 & 0 & 0 \\
\hline Pau-de-óleo 5 & Copaifera langsdorfii Desf. & Caesalpiniaceae & 14 & 0 & 0 \\
\hline Peroba $^{6}$ & Cariniana estrellensis (Raddi) O. Kuntze. & Lecythidaceae & 19 & 19 & 0 \\
\hline Poejo & Mentha pulegium L.* & Lamiaceae & 0 & 0 & 35 \\
\hline Quina & Strychnos brasiliensis (Spreng) Mart. & Loganiaceae & 19 & 0 & 0 \\
\hline Tabucúva & Capsicodendron dinisii (Schwacke) Occhioni & Canellaceae & 0 & 38 & 0 \\
\hline Timbopeva & Paullinia spp.; Serjania spp. & Sapindaceae & 19 & 19 & 0 \\
\hline Urucurana & Hyeronima alchorneoides Allem. & Euphorbiaceae & 21 & 21 & 0 \\
\hline Vacupari & Garcinia gardneriana (Planch \& Triana) Zappi & Clusiaceae & 38 & 0 & 29 \\
\hline
\end{tabular}

${ }^{1}$ or capim-cidró, erva-cidreira, capim-cidrão, capim-cidreira; ${ }^{2}$ or quaresmeira; ${ }^{3}$ or nhacatirão; ${ }^{4}$ or palmito; ${ }^{5}$ or copaíba; ${ }^{6}$ or guatambu. 
known by the local inhabitants, as well as having an area of occurrence that includes type A habitats, or well preserved forests.

Some tree species can be considered as priority for conservation purposes, according to commonness amongst the interviewees, following the criteria of Williams et al. (2005). However, as stressed by Casagrande (2004), we should avoid the danger to conservation strategies of treating knowledge as synonymous with use and cultural importance. The same advice applies when considering that the relationship between knowledge and use are not linear. In the case of the boundaries of Carlos Botelho State Park, the use of forest trees other than E. edulis is usually secondary to this major activity. The challenge presented in this scenario is how we can conserve the forest with such illegal activity. One of the possible answers to this challenge is to focus our conservation efforts on other tree species as well, particularly those which are used as sources of edible fruits and not wood, currently or potentially.

\section{Acknowledgements}

This work was supported by the State of São Paulo Research Foundation (FAPESP) within the BIOTA/ FAPESP - The Biodiversity Virtual Institute Program (www.biota.org.br). N. Hanazaki thanks FAPESP for a post-doctoral grant (01/05596-1), L.G. Araujo and R. Mazzeo for helping in the fieldwork, and the director of Carlos Botelho State Park, J.L.C. Maia. N. Peroni made useful comments on the manuscript. Last, but not least, the authors acknowledge all the local residents who agreed to take part in this research.

\section{References}

Albuquerque, U.P.A.; Andrade, L.H.C. \& Silva, A.C.O. 2005. Use of plant resources in a seasonal dry forest (Northeastern Brazil). Acta Botanica Brasilica 19: 27-38.

Albuquerque, U.P.A. \& Lucena, R.F.P. 2005. Can apparency affect the use of plants by local people in tropical forests? Interciencia 30: 506-511.

Balick, M.J. \& Cox, P.A. 1996. Plants, people and culture. New York, Scientific American Library.

Begossi A. 1996. Use of ecological methods in ethnobotany: diversity indices. Economic Botany 50: 280-289.

Begossi, A.; Hanazaki, N. \& Tamashiro, J.Y. 2002. Medicinal plants and the Atlantic Forest (Brazil): knowledge, use and conservation. Human Ecology 30: 281-299.

Begossi, A.; Leitão Filho, H.F. \& Richerson, P.J. 1993. Plant uses in a Brazilian fishing community (Búzios Island). Journal of Ethnobiology 13: 233-256.
Bennett, B.C. \& Prance, G.T. 2000. Introduced plants in the indigenous pharmacopoeia of Northern South America. Economic Botany 54: 90-102.

Berlin, B. 1992. Ethnobiological Classification. Principles of Categorization of Plants and Animals in Traditional Societies. Princeton, Princeton University Press.

Berlin, B.; Breedlove, D.E. \& Raven, P.H. 1973. General principles of classification and nomenclature in folk biology. American Anthropologist 75: 214-242.

Bernard, H.R. 1995. Research methods in anthropology: qualitative and quantitative approaches. $2^{\text {nd }}$ ed. Walnut Creek, Altamira press.

Cândido, A. 1977. Os parceiros do Rio Bonito. $4^{\text {th }}$ ed. São Paulo, Duas Cidades.

Casagrande, D.G. 2004. Conceptions of primary forest in a Tzeltal Maya community: Implications for conservation. Human Organization 63: 189-202.

Chazdon, R.L. \& Coe, F.G. 1999. Ethnobotany of woody species in second-growth, old-growth, and selectively logged forests of northeastern Costa Rica. Conservation Biology 13: 1312-1322.

Cunha, M.C. \& Almeida, M.W.B. 2000. Indigenous people, traditional people and conservation in the Amazon. Daedalus 129: 315-338.

Custódio Filho, A.; Negreiros, O.C.; Dias, A.C. \& Franco, G.A.D.C. 1992. Composição florística do estrato arbóreo do Parque Estadual de Carlos Botelho, SP. Revista do Instituto Florestal 4: 184-190.

Dalle, S.P. \& Potvin, C. 2004. Conservation of useful plants: An evaluation of local priorities from two indigenous communities in eastern Panama. Economic Botany 58: 38-57.

Dean, W. 1996. A ferro e fogo. São Paulo, Companhia das Letras.

Di Stasi, L.C.; Oliveira, G.P.; Carvalhaes, M.A.; Queiroz Junior, M.; Tien, O.S.; Kakinami, S.H. \& Reis, M.S. 2002. Medicinal plants popularly used in the Brazilian Tropical Atlantic Forest. Fitoterapia 73: 69-91.

Diegues, A.C.S. \& Arruda, R.S.V. 2001. Saberes tradicionais e biodiversidade no Brasil. Brasília, Ministério do Meio Ambiente.

Estomba, D.; Ladio, A. \& Lozada, M. 2006. Medicinal plant knowledge and gathering patterns in a Mapuche community from North-western Patagonia. Journal of Ethnopharmacology 103: 109-119.

Figueiredo, G.M.; Leitão Filho, H.F. \& Begossi, A. 1993. Ethnobotany of Atlantic Forest coastal communities: diversity of plants uses in Gamboa (Itacuruçá island, Brazil). Human Ecology 21: 419-430.

Figueiredo, G.M.; Leitão Filho, H.F. \& Begossi, A. 1997. Ethnobotany of Atlantic Forest coastal communities: II. Diversity of plant uses at Sepetiba bay (SE Brazil). Human Ecology 25: 353-360.

Hanazaki, N. 2004. Métodos ecológicos na investigação etnobotânica: o uso de medidas de diversidade. In: Anais do $5^{\circ}$ Congresso Nacional de Botânica. Viçosa 2004. Viçosa, Sociedade Botânica do Brasil. 
Hanazaki, N.; Peroni, N. \& Begossi, A. 2005. Edible and healing plants in the ethnobotany of native inhabitants of the Amazon and Atlantic Forest areas of Brazil. In: A. Pieroni \& L.L. Price (orgs.). Eating and Healing traditional food as medicine. Binghamton, Haworth Press.

Hanazaki, N.; Tamashiro, J.Y.; Leitão Filho, H.F. \& Begossi, A. 2000. Diversity of plant uses in two Caiçara communities from Atlantic Forest coast, Brazil. Biodiversity and Conservation 9: 597-615.

Hogan, D.J.; Carmo, R.L.; Alves, H.P.F. \& Rodrigues, I.A. 1999. Sustentabilidade no Vale do Ribeira (SP): conservação ambiental e melhoria das condições de vida da população. Ambiente e Sociedade 2: 151-175.

IBGE. 2002. Fundação Instituto Brasileiro de Geografia e Estatística. Base de dados SIDRA II. http:// www.ibge.gov.br

Kawaski, M.L. \& Ladrum, L.R. 1997. A rare and potentially economic fruit of Brazil: cambuci, Campomanesia phaea (Myrtaceae). Economic Botany 51: 403-405.

Kemf, E. 1993. Indigenous peoples and protected areas. London, Earthscan.

La Torre-Cuadros, M.D. \& Islebe, G.A. 2003. Traditional ecological knowledge and use of vegetation in southeastern Mexico: a case study from Solferino, Quintana Roo. Biodiversity and Conservation 12: 2455-2476.

Ladio, A. \& Lozada, M. 2004. Patterns of use and knowledge of wild edible plants in distinct ecological environments: a case study of a Mapuche community from northwestern Patagonia. Biodiversity and Conservation 13: 1153-1173.

Lawrence, A.; Phillips, O.L.; Ismodes, A.R.; Lopez, M.; Rose, S.; Wood, D. \& Farfan, A.J. 2005. Local values for harvested forest plants in Madre de Dios, Peru: towards a more contextualised interpretation of quantitative ethnobotanical data. Biodiversity and Conservation 14: 45-79.

Magurran, A. 1988. Ecological diversity and its measurement. London, Croom Helm.

Matos, D.M.S. \& Bovi, M.L.A. 2002. Understanding the threats to biological diversity in southeastern Brazil. Biodiversity and Conservation 11: 1747-1758.

Medeiros, M.F.T.; Fonseca, V.S. \& Andreata, R.H.P. 2004. Plantas medicinais e seus usos pelos sitiantes da Reserva Rio das Pedras, Mangaratiba, RJ, Brasil. Acta Botanica Brasilica 18: 391-399.

Minnis, P. 2000. Ethnobotany: a reader. Norman, University of Oklahoma Press.

Myers, N.; Mittermeier, R.A.; Mittermeier, C.G.; Fonseca, G.A.B. \& Kent, J. 2000. Biodiversity hot spots for conservation priorities. Nature 403: 853-858.

Orlande, T.; Laarman, J. \& Mortimer, J. 1996. Palmito sustainability and economics in Brazil's Atlantic coastal forest. Forest Ecology and Management 80: 257-265.

Peres, C.A. \& Zimmerman, B. 2001. Perils in parks or parks in peril? Reconciling conservation in Amazonian reserves with and without use. Conservation Biology 15: 793-797.
Peroni, N. \& Hanazaki, N. 2002. Current and lost diversity of cultivated varieties, especially cassava, under swidden cultivation systems in the Brazilian Atlantic Forest. Agriculture, Ecosystems and Environment 92: 171-183.

Quinlan, M.B.; Quinlan, R.J. \& Nolan, J.M. 2002. Ethnophysiology and herbal treatments of intestinal worms in Dominica, West Indies. Journal of Ethnopharmacology 80: 75-83.

Reis, M.S.; Fantini, A.C.; Nodari, R.O.; Reis, A.; Guerra, M.P. \& Mantovani, A. 2000. Management and conservation of natural populations in Atlantic rain forest: The case study of palm heart (Euterpe edulis Martius). Biotropica 32: 894-902.

Ribeiro, D. 1995. O povo brasileiro: a formação e o sentido do Brasil. São Paulo, Companhia das Letras.

Robbins, M.C. \& Nolan, J.M. 1997. A measure of dichotomous category bias in free-listing tasks. Cultural Anthropology Methods Journal 9: 8-12.

Rossato, S.C.; Leitão Filho, H.F. \& Begossi, A. 1999. Ethnobotany of caiçaras of the Atlantic Forest coast (Brazil). Economic Botany 53: 377-385.

Scarano, F.R. 2002. Structure, function and floristic relationships of plant communities in stressful habitats marginal to the Brazilian Atlantic rainforest. Annals of Botany 90: 517-524.

Schimink, M.; Redford, K.H. \& Padoch, C. 1992. Traditional peoples and the Biosphere: framing the issues and defining the terms. Pp. 3-13. In: K.H. Redford \& C. Padoch (eds.). Conservation of neotropical forests: working from traditional resource use. New York, Columbia University Press.

Schultes, R.E. \& Reis, S. 1995. Ethnobotany. Portland, Dioscorides Press.

Schwartzman, S.; Moreira, A. \& Nepstad, D. 2000. Rethinking tropical forest conservation: Perils in parks. Conservation Biology 14: 1351-1357

Silva, A.J.R. \& Andrade, L.H.C. 2005. Etnobotânica nordestina: estudo comparativo da relação entre comunidades e vegetação na Zona do Litoral - Mata do Estado de Pernambuco, Brasil. Acta Botanica Brasilica 19: $45-60$.

Stepp, J.R. 2004. The role of weeds as sources for pharmaceuticals. Journal of Ethnopharmacology 92: 163-166.

Stepp. J.R. \& Moerman, D.E. 2001. The importante of weeds in ethnopharmacology. Journal of Ethnopharmacology 75: 19-23.

Toledo, V.M.; Batis, A.M.; Becerra, R.; Martínez, E. \& Ramos, C. 1995. La selva util: etnobotánica cuantitativa de los grupos indígenas del trópico húmedo de México. Interciencia 20: 177-187.

Trotter, R.T. \& Logan, M.H. 1986. Informant consensus: A new approach for identifying potentially effective medicinal plants. Pp. 91-112. In: N.L. Etkin (ed.). Plants in Indigenous Medicine and Diet. Bedford Hills, Redgrave.

Tuxill, J. \& Nabhan, G.P. 2001. People, plants and protected areas: a guide to in situ management. London, Earthscan. 
Veloso, H.P. \& Góes Filho, L. 1982. Fitogeografia brasileira: classificação fisionômico-ecológica da vegetação Neotropical. Pp. 1-86. In: Brasil (ed.). Boletim Técnico do Projeto Radambrasil (Série Vegetação). Salvador, Ministério das Minas e Energia.

Voeks, R.A. 1996. Tropical Forest healers and habitat preference. Economic Botany 50: 381-400.

Voeks, R.A. 2004. Disturbance pharmacopoeias: medicine and myth from the humid tropics. Annals of the Association of American Geographers 94: 868-888.
Voeks, R.A. \& Leony, A. 2004. Forgetting the forest: Assessing medicinal plant erosion in eastern Brazil. Economic Botany 58(Suppl. S): 294-306.

Williams, V.L.; Witkowski, E.T.F. \& Balkwill, K. 2005. Application of diversity indices to appraise plant availability in the traditional medicinal markets of Johannesburg, South Africa. Biodiversity and Conservation 14: 2971-3001.

Zube, E.H. \& Busch, M.L. 1990. Park-people relationships: an International review. Landscape and Urban Planning 19: $117-131$. 